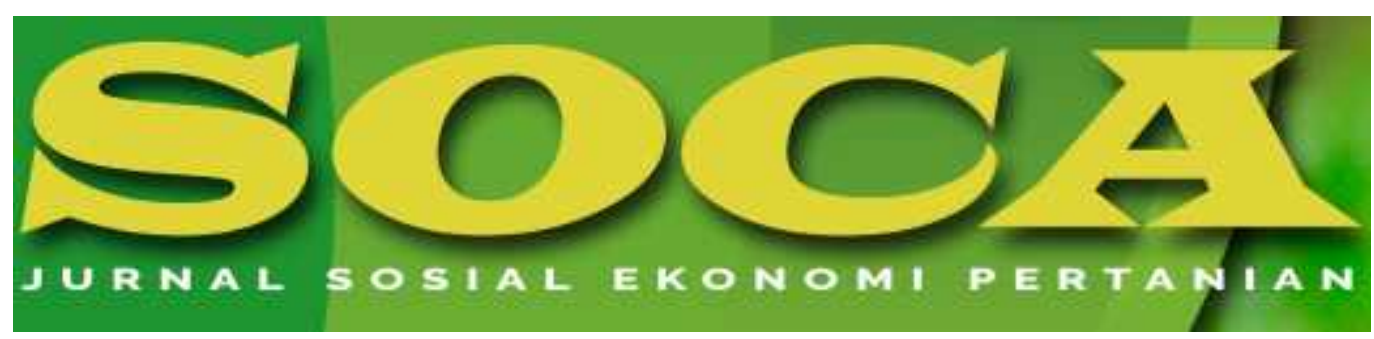

https://ojs.unud.ac.id/index.php/soca

\title{
SIKAP PETANI TERHADAP PRODUK BANK SYARIAH MANDIRI DI KECAMATAN GUBUG KABUPATEN GROBOGAN
}

\author{
Sella Setya Sahanaya, Sriroso Satmoko dan Tutik Dalmiyatun \\ Program Studi Agribisnis, Fakultas Peternakan dan Pertanian, Universitas Diponegoro \\ Email Korespondensi: sellasahanaya14@gmail.com
}

Hp: (085640652656)

\begin{tabular}{l} 
Kata Kunci: \\
faktor \\
pembentuk \\
sikap, produk \\
Bank Syariah \\
Mandiri, sikap \\
petani. \\
\hline
\end{tabular}

\begin{abstract}
Abstrak
Bank merupakan lembaga keuangan yang penting dalam menunjang pertumbuhan perekonomian serta bank juga menjadi alternatif sumber permodalan bagi petani untuk memenuhi kebutuhan sarana produksi pertanian. Penelitian ini bertujuan untuk menganalisis faktor-faktor yang mempengaruhi sikap petani terhadap produk Bank Syariah Mandiri, menganalisis sikap petani terhadap produk bank syariah Mandiri, menganalisis pengaruh faktor-faktor yang mempengaruhi sikap petani meliputi umur, pendidikan, lamanya usahatani, jumlah tanggungan keluarga serta pendapatan terhadap produk bank syariah Mandiri di Kecamatan Gubug kabupaten Grobogan. Metode yang digunakan pada penelitian ini yaitu metode survei. Penelitian dilaksanakan pada bulan 14 Juni - 30 Juli 2019 di Desa Trisari, Kecamatan Gubug, Kabupaten Grobogan. Lokasi penelitian dipilih secara disengaja (purposive). Metode penentuan jumlah sampel yang digunakan yaitu Purposive Sampling dengan menggunakan teknik non probability. Jumlah responden 47 orang kelompok Tani Subur Makmur. Data dianalisis dengan analisis deskriptif untuk menganalisis sikap petani dan faktor-faktor pembentuk sikap petani terhadap produk bank syariah Mandiri sedangkan analisis kuantitatif digunakan untuk mengetahui pengaruh antara faktor pembentuk sikap dengan sikap petani pada produk bank syariah Mandiri di Kecamatan Gubug Kabupaten Grobogan dengan menggunakan regresi linier berganda. Sikap petani terhadap produk bank Syariah Mandiri dalam kategori setuju dengan skor $77,78 \%$. Berdasarkan uji F menunjukkan bahwa secara serempak ada pengaruh yang signifikan antara umur petani, tingkat pendidikan, lamanya usahatani, jumlah tanggungan keluarga, dan pendapatan pada Sikap Petani
\end{abstract}


terhadap Produk bank Syariah Mandiri di Kecamatan Gubug Kabupaten Grobogan. Berdasarkan uji t didapatkan hasil bahwa umur petani, tingkat pendidikan dan pendapatan secara parsial berpengaruh pada Sikap Petani terhadap Produk bank Syariah Mandiri. Lamanya usahatani serta jumlah tanggungan keluarga secara parsial tidak berpengaruh pada Sikap Petani terhadap Produk bank Syariah Mandiri.

\section{ATTITUDE OF FARMERS ON SYARIAH MANDIRI BANKING PRODUCT GUBUG DISTRICT, GROBOGAN REGENCY}

\section{Keywords:}

attitude forming factors, Bank Syariah Mandiri products, attitudes farmers.

\begin{abstract}
Abstrak
Bank was one of the important financial institutions in supporting economic growth, the bank was being an alternative source of capital for farmers to meet the needs of agricultural production facilities. This study aims to analyze the factors that influence the attitudes of farmers towards Bank Syariah Mandiri products, analyze the attitudes of farmers toward Bank Syariah Mandiri products, analyze the influence of factors that influence the attitudes of farmers including education, age duration of farming, number of family dependents and income towards Bank Syariah Mandiri products

in Grobogan Regency Gubug District. The method used in this study is a survey method. The study was conducted on Juny 14-July 30, 2019
\end{abstract} in Trisari Village, Gubug District, Grobogan Regency. Research location was chosen intentionally and the method of determining the number of samples used is purposive sampling with non-probability techniques. The number of respondents is 47 people from the Farmer Group Subur Makmur. Data analyzed with descriptive analysis to analyze the attitudes of farmers, and the factors forming farmers 'attitudes towards Bank Syariah Mandiri Products while the quantitative analysis was used to determine the effect of attitude forming factors with farmers' attitudes towards Bank Syariah Mandiri Products in the Gubug District using multiple linear regression. Farmer's attitude towards Bank Syariah Mandiri Products in the category good/like with a score of $77.78 \%$. Based on the F test shows that simultaneously there is a significant influence between the age of the farmer, the length of farming, the level of education the number of family dependents, and the income of farmers' Attitudes towards Bank Mandiri Syariah Products in Grobogan District. The length of farming, and the number of family dependents partially do not affect the farmers' attitudes towards Bank Syariah Mandiri Products. Based on the $t$ test, the results show that the age of the farmer, the level of education, and income partially influences the attitude of the Farmers towards Bank Syariah Mandiri 


Products. Keyword: attitude forming factors,
Bank Syariah Mandiri products, attitudes of farmers.

How to Cite (APA 6 ${ }^{\text {th }}$ Style):

Sahanaya, S. S., Satmoko, S., \& Dalmiyatun, T. (2020). Sikap Petani Terhadap Produk Bank Syariah Mandiri Di Kecamatan Gubug Kabupaten Grobogan. SOCA: Jurnal Sosial Ekonomi Pertanian, 14(1), 114-131. https://doi.org/https://doi.org/10.24843/SOCA.2020.v14.i01.p10

\section{PENDAHULUAN}

Bank merupakan salah satu lembaga keuangan yang penting dalam menunjang pertumbuhan perekonomian, bank menjadi alternatif sumber permodalan bagi petani untuk memenuhi kebutuhan sarana produksi pertanian, mayoritas masyarakat di Indonesia beragama islam terutama masyarakat petani, adanya perkembangan ekonomi serta kebutuhan untuk memenuhi permodalan menjadi peluang bagi bank syariah agar dimanfaatkan oleh petani sebagai sumber modal. Petani merupakan salah satu mitra bank yang membutuhkan modal untuk mengelola pertanian yang mereka miliki, penting bagi petani untuk memahami produk serta mekanisme pembiayaan syariah yang menjadi salah satu alternatif dari jasa perbankan yang sudah ada.

Kecamatan Gubug adalah salah satu Kecamatan yang ada di Kabupaten Grobogan Provinsi Jawa Tengah. Terdapat 21 desa yang ada disana dan salah satunya yaitu Desa Trisari. Desa Trisari memiliki wilayah seluas 277,01 Ha sedangkan Kecamatan Gubug mempunyai luas 7.111,25 ha. Kecamatan Gubug terdiri dari lahan sawah sebesar 3.313,46 Ha, Lahan tanah kering sebesar 3.797,79 Ha. Lahan pertanian sawah tersebut yang tergolong dalam lahan irigasi sebesar 3.176,52 Ha, lahan tadah hujan sebesar 136,94 Ha. Lahan tanah kering terdiri dari Tegalan/kebun sebesar 586,29 Ha, Pekarangan sebesar 1.601,50 Ha, Perkebunan 0 Ha, Hutan Negara 1.182,90 Ha, Kolam atau tambak $0 \mathrm{Ha}$, dan lainnya sebesar 427,10 Ha. Bagian pendidikan menunjukkan bahwa sebagian besar responden memiliki pendidikan yang rendah yaitu lulusan SD sebesar $63,82 \%$. Sedangkan untuk lulusan DIII sebesar 2,12\%. Hal ini menunjukkan sebagian besar kelompok tani Subur Makmur masih belum menyadari pentingnya pendidikan. Kondisi tersebut berpengaruh terhadap produk yang di berikan bank syariah menjadi sebuah produk yang mudah untuk dipahami serta masuk kepada masyarakat. Bank syariah Mandiri menerapkan sistem bagi hasil yang adil, bank syariah Mandiri menggunakan prinsip Syariah islam dan petani dengan mudah memahami produk yang disediakan oleh Bank Syariah Mandiri, petani mengetahui hal tersebut melalui teman, brosur dan leaflet. Secara afektif sikap petani terhadap produk bank syariah Mandiri sebesar $77,70 \%$, para petani senang atau suka dengan produk yang disediakan oleh Bank syariah Mandiri, petani merasa bahwa Bank Syariah Mandiri memiliki manfaat untuk petani dalam memenuhi kebutuhan permodalan untuk usahatani yang mereka miliki, produk yang ditawarkan berupa produk penghimpun dana dari masyarakat (funding), produk penyaluran dana kepada masyarakat (financing) serta pelayanan jasa (Fee based income product) yang membuat petani tertarik untuk menggunakannya, petani tertarik dan senang untuk menggunakan 
produk bank syariah Mandiri karena produk yang ditawarkan bank syariah Mandiri menggunakan prinsip syariah yaitu bebas bunga dan sistem bagi hasil. Berdasarkan hasil perhitungan skor sikap menunjukkan bahwa sikap petani terhadap produk bank syariah Mandiri dalam kategori setuju/baik dengan skor rata-rata 77,78\%.

Tujuan penelitian ini untuk menganalisis sikap petani terhadap produk Bank Syariah Mandiri di Kecamatan Gubug kabupaten Grobogan, menganalisis faktorfaktor yang mempengaruhi sikap petani terhadap produk Bank Syariah Mandiri di Kecamatan Gubug Kabupaten Grobogan, menganalisis pengaruh faktor-faktor pembentuk sikap meliputi umur, pendidikan, lamanya berusahatani, jumlah tanggungan keluarga dan pendapatan terhadap sikap petani dalam produk bank syariah Mandiri di Kecamatan Gubug kabupaten Grobogan.

\section{METODE PENELITIAN}

Penelitian dilaksanakan pada tanggal 14 Juni - 30 Juli 2019 di Desa Trisari Kecamatan Gubug Kabupaten Grobogan. Penentuan lokasi tersebut dipilih secara sengaja atau Purposive dengan pertimbangan lokasi tersebut dipilih karena memiliki kelompok tani yang sudah maju, pendapatan utama petani didapatkan dari usahatani, mengetahui lembaga keuangan perbankan dan letak geografis yang strategis sehingga akses menuju Bank Syariah Mandiri di Kecamatan Gubug Kabupaten Grobogan jauh lebih mudah. Penelitian dilakukan dengan menggunakan metode survei. Metode survei merupakan metode riset yang menggunakan kuesioner sebagai instrument pengumpulan datanya. Tujuannya yaitu untuk memperoleh informasi tentang sejumlah responden yang dianggap mewakili populasi tertentu (Ardiansyah, 2010).

Metode untuk penentuan jumlah sampel yang digunakan yaitu Purposive Sampling dengan teknik non probability. Jumlah responden 47 orang kelompok Tani Subur Makmur. Data dianalisis dengan analisis deskriptif untuk menganalisis sikap petani dan faktor-faktor pembentuk sikap petani terhadap produk bank syariah Mandiri sedangkan analisis kuantitatif digunakan untuk mengetahui pengaruh antara faktor pembentuk sikap dengan sikap petani terhadap produk bank syariah Mandiri di Kecamatan Gubug Kabupaten Grobogan dengan menggunakan regresi linier berganda. Data primer dan data sekunder adalah data yang digunakan dalam penelitian ini. Data primer diperoleh dari hasil pengisian kuesioner, wawancara langsung pada responden serta observasi. Data sekunder diperoleh dari hasil studi pustaka dengan mencari data dari buku, jurnal, maupun catatan dari sumber dan dinas terkait. Data yang telah diperoleh kemudian dilakukan analisis sebagai berikut:

Variabel yang diukur dalam penelitian ini terdiri dari variabel Tidak Bebas (Y) sikap petani terhadap produk Bank Syariah Mandiri diukur dengan menggunakan nilai skor 1-5. Responden akan diminta untuk memilih sejumlah kategori yang tersedia dari variabel yang ada, kemudian diukur dengan skala pengukuran sikap likert.

Kriteria interpretasi:

1. Angka $0 \%-19,99 \%$

2. Angka $20 \%-39,99 \%$

= sangat (tidak setuju/buruk/kurang sekali)

3. Angka $40 \%-59,99 \%$

= tidak setuju/ kurang baik

= cukup/ netral 
4. Angka $60 \%-79,99 \%$

$=$ setuju/baik

5. Angka $80 \%-100 \%$

= sangat (setuju/baik/suka) (Nazir, 2005).

Variabel (X) diukur dari beberapa indikator faktor pembentuk sikap meliputi:

$\mathrm{X} 1$ : umur petani

$\mathrm{X} 2$ : tingkat pendidikan petani

X3: lamanya usahatani

X4: jumlah tanggungan keluarga

X5: pendapatan

\section{Analisis Regresi Linier Berganda}

Sesuai dengan tujuan penelitian, metode analisis data yang digunakan adalah analisis regresi linier berganda. Analisis regresi akan menentukan suatu persamaan yang menaksir sifat pengaruh fungsional antara variabel dependen dengan variabel-variabel independen (Sukirno, 2014). Formulasi analisis regresi linier berganda yang digunakan adalah:

$$
\mathrm{Y}=\mathrm{a}+\mathrm{b} 1 \mathrm{X} 1+\mathrm{b} 2 \mathrm{X} 2+\mathrm{b} 3 \mathrm{X} 3+\mathrm{b} 4 \mathrm{X} 4+\mathrm{b} 5 \mathrm{X} 5+\mu \mathrm{e}
$$

Keterangan:

$\mathrm{Y}=$ Sikap Petani terhadap Produk bank syariah

$\mathrm{a}=$ Konstanta

$\mathrm{b}=$ koefisien regresi untuk masing-masing variabel

$\mathrm{X} 1=$ umur petani (tahun)

$\mathrm{X} 2=$ tingkat pendidikan petani (tahun)

X3= lamanya usahatani (tahun)

$\mathrm{X} 4=$ jumlah tanggungan keluarga (jiwa)

$\mathrm{X} 5=$ pendapatan petani (Rupiah)

$\mathrm{e}=$ variabel pengganggu

\section{Uji f}

Uji f digunakan untuk menguji variabel-variabel tersebut apakah berpengaruh terhadap sikap petani terhadap Bank Syariah Mandiri, maka digunakan analisis uji $\mathrm{f}$.

Kreteria uji serempak adalah:

$\mathrm{F}$ hitung > $\mathrm{F}$ tabel: maka $\mathrm{H}_{\mathrm{o}}$ ditolak dan $\mathrm{H}_{1}$ diterima

$\mathrm{H}_{1}$ diterima artinya variabel bebas secara bersamaan berpengaruh nyata terhadap variabel terikat pada tingkat kepercayaan tertentu.

$\mathrm{F}$ hitung $\leq \mathrm{F}$ tabel: maka $\mathrm{H}_{\mathrm{o}}$ diterima dan $\mathrm{H}_{1}$ ditolak

$\mathrm{H}_{\mathrm{o}}$ diterima artinya variabel bebas secara bersama-sama tidak berpengaruh nyata terhadap variabel terikat pada tingkat kepercayaan tertentu (Hasan 2006).

\section{Uji t}

Uji t digunakan untuk menguji variabel-variabel tersebut apakah secara parsial berpengaruh terhadap sikap petani, maka digunakan analisis uji t

Kreteria uji t adalah:

t hitung $>\mathrm{t}$ tabel maka HO ditolak

t hitung $\leq \mathrm{t}$ tabel maka. HO diterima (Hasan, 2006). 
Pengambilan keputusan uji t adalah apabila sig > 0,05 maka Ho diterima dan Ha ditolak, sedangkan apabila sig $\leq 0.05$ maka ho ditolak dan Ha diterima (Sujarweni 2015).

\section{HASIL DAN PEMBAHASAN}

\section{Gambaran Umum Kecamatan Gubug}

Kecamatan Gubug merupakan salah satu Kecamatan yang ada di Kabupaten Grobogan Provinsi Jawa Tengah. Terdapat 21 desa yang ada di Kecamatan Gubug salah satunya yaitu Desa Trisari. Desa Trisari memiliki luas wilayah 277,01 Ha sedangkan Kecamatan Gubug sendiri mempunyai luas 7.111,25 ha. Kecamatan Gubug terdiri dari lahan sawah sebesar 3.313,46 Ha, Lahan tanah kering sebesar 3.797,79 Ha. Lahan pertanian sawah tersebut yang tergolong dalam lahan irigasi sebesar 3.176,52 Ha, lahan tadah hujan sebesar 136,94 Ha. Lahan tanah kering terdiri dari Tegalan/kebun sebesar 586,29 Ha, Pekarangan sebesar 1.601,50 Ha, Perkebunan 0 Ha, Hutan Negara 1.182,90 Ha, Kolam atau tambak 0 Ha, dan lainnya sebesar 427,10 Ha. Batas utara yaitu Kecamatan Kebonagung Kabupaten Demak, Batas selatan Kecamatan Tanggungharjo, Batas barat Kecamatan Tegowanu, Batas timur Kecamatan Godong dan Karangrayung. Desa Trisari terbagi menjadi 3 dusun, 4 RW, 14 RT dan 1.039 KK. Penduduk Desa Trisari berjumlah 2.673 jiwa terdiri dari 1.462 laki-laki dan 1.443 perempuan. Desa Trisari terletak di wilayah yang merupakan dataran rendah dengan ketinggian 13 mdpl menyebabkan desa Trisari sangat subur sehingga menghasilkan potensi pertanian seperti jagung, padi, serta palawija. Luas panen tanaman pangan di desa Trisari untuk padi yaitu sebesar 467 Ha.

\section{Keadaan Umum Kelompok Tani Subur Makmur}

Obyek yang menjadi responden pada penelitian ini adalah petani di kelompok tani Subur Makmur Desa Trisari, Kecamatan Gubug, Kabupaten Grobogan. Jumlah responden yang dijadikan ssebagai ampel adalah 47 orang. Mayoritas responden menjadikan usahatani sebagai pekerjaan utama untuk memenuhi kebutuhan hidup. Karakteristik responden pada penelitian ini meliputi jenis kelamin, umur, lamanya usahatani, tingkat pendidikan, jumlah anggota keluarga serta pendapatan yang dimiliki.

Responden seluruhnya didominasi oleh laki-laki sebanyak 47 orang hal tersebut menunjukkan bahwa sebagian besar petani adalah laki-laki karena pekerjaan dilakukan diluar ruangan dan laki-laki sebagai tulang punggung keluarga yang bekerja untuk memenuhi kebutuhan hidupnya. Pekerjaan sebagai petani membutuhkan tenaga yang besar untuk mengelola lahan pertanian yang dimiliki sehingga hal tersebut dapat dilakukan oleh petani laki-laki. Biasanya perempuan hanya akan membantu dalam urusan rumah tangga atau terkadang menggantikan laki-laki untuk menghadiri rapat rutinan yang dilakukan oleh kelompok tani pada saat suami mereka tidak dapat mengahadiri rapat rutin yang diselenggarakan disana.

Kelompok Tani di desa Trisari Kecamatan Gubug Kabupaten Grobogan berdiri sejak 28 Desember 2009 dan didirikan oleh petani di desa Trisari dan atas bantuan PPL (Petugas Penyuluh Lapangan) dengan nama Kelompok Tani Subur Makmur. PPL berfungsi sebagai pembimbing pada kelompok tani Subur Makmur untuk 
memberikan arahan kepada petani agar dapat memajukan pertanian yang mereka jalani. Petani di Desa Trisari kecamatan Gubug kabupaten Grobogan merupakan petani hamparan dan petani domisili. Responden merupakan petani hamparan yakni petani yang memiliki hamparan lahan usahatani yang sama. Kelompok tani Subur Makmur menerapkan sistem pertanian monokultur dengan komoditas yang ditanam berupa padi karena tanaman padi merupakan tanaman pangan yang penting guna memenuhi bahan pokok bagi petani serta masyarakat. Hal ini sesuai dengan pendapat Ishaq et al., (2017) yang menyatakan bahwa tanaman padi merupakan tanaman budidaya yang sangat penting bagi umat manumur dan menjadi sumber bahan utama bagi hampir setengah penduduk dunia.

Kelompok tani ini memiliki agenda rutin setiap tahun seperti penanaman padi secara serentak, pemupukan, penyemprotan tanaman padi, pemberantasan tikus menggunakan burung hantu dan berbagai agenda lainnya sesuai dengan arahan PPL. Agenda rutin pemeliharaan tanaman padi dilakukan secara berkala setiap 2 bulan sekali. Selain itu kelompok tani ini juga menyediakan peminjaman alat-alat pertanian seperti traktor untuk pengolahan lahan. Hal ini sesuai dengan pendapat (Sinuraya, M., Barus, A. Hasanah 2015) yang menyatakan bahwa pemupukan merupakan salah satu teknik budidaya yang harus diterapkan untuk mendapatkan produksi tanaman yang tinggi, pemupukan digunakan untuk merangsang tanaman agar lebih cepat berbuah selain dilakukan melalui akar, pemberiannya dapat juga melalui daun dengan cara disemprotkan.

Adanya kelompok tani Subur Makmur ini diharapkan mampu menjawab persoalan yang dihadapi petani serta sebagai wadah bagi petani untuk saling bertukar pikiran dan berdiskusi. Kelompok Tani Subur Makmur juga memiliki seksi simpan pinjam yang berguna untuk menghimpun dana dari anggota kelompok dan arisan rutin sehingga setiap bulannya pertemuan dapat dilaksanakan. Dana arisan yang terkumpul dapat dipinjamkan kepada petani lain yang membutuhkan modal dengan sukarela. Petani menggunakan bantuan lembaga keuangan bank dan bukan bank dalam menjalankan usahatani yang mereka miliki. Hal tersebut sesuai dengan pendapat (Junanda 2018) yang menyatakan bahwa lembaga keuangan dibedakan menjadi dua yaitu bank dan bukan bank, lembaga bukan bank merupakan semua badan usaha yang kegiatannya dibidang keuangan.

\section{Faktor-faktor yang mempengaruhi sikap petani terhadap produk Bank Syariah Mandiri di Kecamatan Gubug Kabupaten Grobogan}

Pada penelitian yang ada sebelumnya berjudul "Faktor-faktor yang mempengaruhi keputusan petani memilih lembaga keuangan syariah sebagai sumber kredit" oleh Arifandi menunjukkan bahwa secara serempak faktor umur, tingkat pendidikan, jumlah tanggungan, pendapatan, prosedur kredit mempengaruhi keputusan petani memilih lembaga keuangan syariah sebagai sumber kreditnya. Hal ini diperoleh dari hasil signifikansi yang diperoleh sebesar 0,00 atau $a<0.05$. Secara parsial diperoleh umur dan pendapatan mempengaruhi keputusan petani untuk memilih lembaga keuangan syariah sebagai sumber kreditnya. Hal ini diperoleh dari hasil signifikansi yang diperoleh untuk variabel umur sebesar $0.02<0,05$ dan variabel pendapatan sebesar $0,00<0,05$. Sedangkan untuk tingkat pendidikan, jumlah tanggungan, serta prosedur kredit tidak mempengaruhi keputusan petani dalam memilih lembaga keuangan syariah sebagai sumber kredit. Hal ini diperoleh 
dari signifikansi untuk masing-masing variable tingkat pendidikan sebesar 0,79, jumlah tanggungan sebesar 0,29, dan prosedur kredit sebesar 0,27. Selanjutnya pada penelitian yang berjudul "Faktor-fakor yang mempengaruhi preferensi petani dalam menjual hasil pertaniannya" oleh Charlie Malewa menunjukkan hasil bahwa umur sebesar $0.02<0,05$ dan variabel pendapatan sebesar 0,00 0,05. Sedangkan untuk tingkat pendidikan, jumlah tanggungan, dan prosedur kredit tidak mempengaruhi keputusan petani dalam memilih lembaga keuangan syariah sebagai sumber kredit. Hal ini diperoleh dari signifikansi untuk masing-masing variable tingkat pendidikan sebesar 0,79, jumlah tanggungan sebesar 0,29, dan prosedur kredit sebesar 0,27.

Pada penelitian ini memiliki perbedaan dari kedua penelitian sebelumnya, pada penelitian ini menjelaskan mengenai faktor yang mempengaruhi sikap petani terhadap produk bank syariah Mandiri di Kecamatan Gubug Kabupaten Grobogan pada penelitian ini meliputi faktor karakteristik sosial ekonomi yaitu umur, lamanya usahatani, tingkat pendidikan, jumlah anggota keluarga dan pendapatan yang telah diuraikan pada Tabel dibawah ini

Tabel 1. Jumlah Dan Persentase Responden Berdasarkan Umur, Pendidikan, Pendapatan per Bulan, Jumlah Tanggungan Keluarga dan Lamanya Usahatani

\begin{tabular}{|c|c|c|}
\hline \multirow{2}{*}{ Keterangan } & \multicolumn{2}{|c|}{ Karakteristik Responden } \\
\hline & Jumlah & Persentase \\
\hline Umur (Tahun) & --orang-- & $\begin{array}{c}-\%-- \\
--\end{array}$ \\
\hline$<31$ & 0 & 0 \\
\hline $31-40$ & 9 & 19,14 \\
\hline $41-50$ & 15 & 31,91 \\
\hline $51-64$ & 17 & 36,18 \\
\hline$>64$ & 6 & 12,77 \\
\hline Jumlah & 47 & 100 \\
\hline \multicolumn{3}{|l|}{ Pendidikan } \\
\hline Tidak Lulus SD & 0 & 0 \\
\hline $\mathrm{SD}$ & 30 & 63,82 \\
\hline SMP & 12 & 25,54 \\
\hline SMA & 4 & 8,52 \\
\hline DIII & 1 & 2,12 \\
\hline Jumlah & 47 & 100 \\
\hline \multicolumn{3}{|l|}{ Pendapatan per bulan } \\
\hline$\leq \mathrm{Rp} \mathrm{500.000,-}$ & 7 & 14,89 \\
\hline$>$ Rp 500.000,- - Rp 1.000.000,- & 19 & 40,42 \\
\hline$>$ Rp 1.000.000,- - Rp 3.000.000,- & 16 & 34,04 \\
\hline$>\operatorname{Rp} 3.000 .000,--\operatorname{Rp} 5.000 .000,-$ & 5 & 10,63 \\
\hline$>$ Rp 5.000.000,- & 0 & 0,00 \\
\hline Jumlah & 46 & 100 \\
\hline \multicolumn{3}{|l|}{ Jumlah tanggungan keluarga } \\
\hline $1-3$ & 18 & 38,29 \\
\hline $4-6$ & 29 & 61,71 \\
\hline
\end{tabular}




\begin{tabular}{ccc}
$>6$ & 0 & 0 \\
\hline Jumlah & 47 & 100 \\
\hline Lamanya usahatani & & 23,41 \\
$1-10$ & 11 & 31,91 \\
$11-20$ & 15 & 40,42 \\
$21-30$ & 19 & 4,25 \\
$31-40$ & 2 & 0 \\
$>40$ & 0 & 100 \\
\hline Jumlah & 47 &
\end{tabular}

Sumber: Data Primer Diolah, 2019

Berdasarkan Tabel 1. dapat dilihat bahwa mayoritas responden berumur 5164 tahun dengan persentase responden sebesar 36,18\% dan responden umur $41-$ 50 tahun sebesar 31,91\%. Besarnya persentase tersebut telah menunjukkan bahwa sebagian besar responden masih berumur produktif serta bekerja sehingga dapat menjalankan usahatani mereka. Umur tertinggi >64 tahun sebesar $12,77 \%$ menunjukan bahwa masih ada petani yang umurnya sudah tidak produktif akan tetapi masih menjalankan usahatani yang dimilikinya untuk memenuhi kebutuhan hidup. Umur berpengaruh terhadap kemampuan kerja seorang petani, semakin tua umur petani maka kemampuan kerja juga menurun. Hal ini sesuai dengan pendapat (Mantra 2003) yang menyatakan bahwa kelompok umur 0-14 tahun dianggap sebagai kelompok penduduk yang belum produktif secara ekonomi sedangkan kelompok penduduk pada umur 15-64 tahun sebagai kelompok produktif dan kelompok umur 65 tahun ke atas sebagai kelompok penduduk yang sudah tidak produktif lagi.

Responden yang tergolong umur produktif memiliki kemampuan fisik yang kuat sehingga dapat bekerja dengan optimal. umur yang sudah matang juga menentukan kemampuan petani dalam berfikir sehingga dapat mengambil keputusan yang tepat dalam menjalankan usahatani. Hal ini sesuai dengan pendapat (Rukka, H. dan A 2013) yang menyatakan bahwa umur merupakan suatu aspek yang berpengaruh terhadap kemampuan fisik, psikologis serta biologis seseorang.

Bagian pendidikan menunjukkan sebagian besar responden memiliki pendidikan yang rendah yaitu lulusan SD sebesar 63,82\%. Sedangkan untuk lulusan DIII sebesar 2,12\%. Hal ini menunjukkan sebagian besar kelompok tani Subur Makmur masih belum menyadari pentingnya pendidikan. Selain itu juga disebabkan oleh keterbatasan ekonomi serta kebudayaan yang dimiliki oleh petani, rata-rata petani hanya lulusan SD sehingga sebagian besar lebih memilih bekerja untuk mencukupi kebutuhan daripada melanjutkan pendidikan, petani dengan pendidikan tinggi termasuk dalam jumlah yang kecil hal ini dikarenakan sebagian besar petani tidak memprioritaskan status pendidikan untuk bekerja sebagai petani karena petani hanya memerlukan modal tenaga dan pengalaman dalam menjalankan usahatani, pendidikan menjadi salah satu faktor yang mempengaruhi sikap petani. Hal ini sesuai dengan pendapat (Azwar 2013) yang menyatakan bahwa berbagai faktor yang mempengaruhi pembentukan sikap salah satunya adalah pendidikan. 
Petani yang memiliki pendidikan yang cukup dapat berkomunikasi dengan baik sehingga adanya interaksi antar petani dapat menimbulkan terjadinya hubungan timbal balik keduanya yang mempengaruhi sikap petani dalam penerimaan informasi. Hal ini sesuai dengan pendapat (Ahmadi 2009) yang menyatakan bahwa sikap dapat dibentuk atau diubah apabila terdapat hubungan timbal balik yang langsung antara manusia serta adanya komunikasi. Diperkuat oleh pendapat (Oktavia 2018) yang menyatakan bahwa prestasi belajar yang didapatkan oleh seorang individu bisa digunakan untuk mengetahui taraf kemampuannya, dari individu tersebut masuk sekolah hingga pendidikan terakhir yang dia capai. Pendidikan memungkinkan seseorang mendapatkan pengalaman, pengetahuan, baik secara otomatis maupun praktis mengenai objek sikap mengenai individu tersebut.

Berdasarkan Tabel 1. pada bagian jumlah pendapatan, responden dengan pendapatan $>$ Rp500.000,- - Rp1.000.000,- per bulan dengan persentase sebesar $40,42 \%$ dan responden dengan pendapatan $>$ Rp 3.000.000,- - Rp 5.000.000,- per bulan persentasenya sebesar $10,63 \%$. Hal ini menunjukan bahwa petani masih membutuhkan pendapatan yang lebih besar untuk memenuhi kebutuhan perekonomiannya serta berbagai hal lain untuk kebutuhan sarana dan prasarana pertanian sehingga pendapatan berpengaruh terhadap sikap yang mereka miliki. Hal ini sesuai dengan pendapat (Azmi, Mhd.Rullyanda, Hasman Hasyim 2013) yang menyatakan bahwa karakteristik sosial ekonomi salah satunya yaitu pendapatan mempengaruhi sikap petani serta segala aspek kehidupan petani dalam memenuhi kebutuhan ekonomi.

Petani juga mampu menggunakan sumberdaya secara efisien dalam pengelolaan usahatani yang dimilki dengan meningkatkan pendapatan melalui usahatani. Hal ini diperkuat oleh (Fauziyah 2010) yang menyatakan bahwa petani yang menggunakan sumberdaya secara efisien akan mampu mengeksploitasi atau menggali seluruh potensi sumberdaya usahatani untuk meningkatkan pendapatan.

Bagian jumlah tanggungan keluarga setiap petani memiliki tanggungan keluarga sebesar 1-6 orang. Jumlah responden dengan tanggungan keluarga 1-3 orang sebesar 38,29\%, sedangkan jumlah responden dengan tanggungan keluarga terbesar yakni 4-6 orang sebesar 61,71\%. Petani yang memiliki tanggungan keluarga besar membutuhkan pendapatan yang besar pula untuk memenuhi kebutuhan sehari-hari sehingga mereka juga memiliki pekerjaan sampingan seperti menjadi buruh, berdagang serta pekerjaan lainnya. Semakin banyak tanggungan keluarga maka semakin banyak kebutuhan petani untuk memenuhi tanggungan keluarganya. Banyaknya tanggungan keluarga yang dimilki akan mempengaruhi pengeluaran petani. Hal tersebut sesuai dengan pendapat (Gusfrianti and Budiartiningsih 2010) yang menyatakan bahwa jumlah tanggungan keluarga mempunyai pengaruh terhadap peningkatan pendapatan petani.

Berdasarkan Tabel 1. Pengalaman usahatani pada responden berbeda-beda, responden memiliki pengalaman usahatani mulai dari 1-40 tahun, responden dengan pengalaman usahatani 21-30 tahun sebesar 40,42\% sedangkan pengalaman usahatani 31-40 tahun sebesar 4,25\%.

Semakin lama pengalaman usahatani maka semakin terampil serta kompeten dalam menjalankan pekerjaan. Lamanya usahatani dapat juga mendukung petani 
untuk mengembangkan usahataninya, petani yang sudah memiliki banyak pengalaman tentunya dapat menghadapi masalah-masalah yang seringkali terjadi.

Pengalaman usahatani yang dimiliki akan menentukan seberapa besar kemampuan petani dalam menjalankan usahataninya. Hal tersebut sesuai dengan pendapat yang menyatakan bahwa setiap petani memahami aspek teknis dan non teknis dalam kegiatan usahatani. Semakin lama usahatani maka semakin banyak pembelajaran yang dimiliki oleh petani. Selain itu pengalaman bertani berpengaruh pada sikap petani terhadap inovasi maupun teknologi baru. Hal ini sesuai dengan pendapat (Sitopu, Fauzia, and Jufri 2014) yang menyatakan bahwa lama pengalaman yang dimiliki dapat mempengaruhi kemudahan diri dalam menerima inovasi dari luar.

\section{Sikap petani terhadap produk Bank syariah Mandiri}

Sikap petani terhadap produk bank syariah Mandiri di Kecamatan Gubug Kabupaten Grobogan pada penelitian ini mencakup komponen kognitif, afektif dan konatif, pengukuran skor sikap petani terhadap produk bank Syariah Mandiri terangkum dalam tabel dibawah :

Tabel 2. Persentase dan Kategori Jumlah Skor Sikap

\begin{tabular}{ccc}
\hline Jumlah skor & Presentase $(\%)$ & Kategori \\
\hline Kognitif & 78,04 & Setuju/baik \\
Afektif & 77,70 & Setuju/baik \\
Konatif & 77,61 & Setuju/baik \\
\hline Rata-rata & 77,78 & Setuju/baik \\
\hline
\end{tabular}

Sumber: Data Primer Diolah, 2019

Berdasarkan data hasil perhitungan skor untuk sikap menunjukkan bahwa sikap petani terhadap produk bank syariah Mandiri dalam kategori setuju atau baik dengan skor rata-rata 77,78\%. Secara kognitif sebesar 78,04\% petani memiliki pengetahuan yang baik terhadap produk Bank Syariah Mandiri karena bank syariah Mandiri menerapkan sistem bagi hasil yang adil, bank syariah Mandiri menggunakan prinsip Syariah islam dan petani dengan mudah memahami produk yang disediakan oleh Bank Syariah Mandiri, petani mengetahui hal tersebut melalui teman, brosur dan leaflet. Hal ini sesuai dengan pendapat (Marimin and Romdhoni 2017) yang menyatakan bahwa bank syariah adalah badan usaha yang menjalankan aktivitasnya berdasarkan prinsip syariah baik penghimpunan dana maupun penyaluran dana dengan memberikan imbalan atas dasar prinsip syariah.

Secara afektif sikap petani terhadap produk bank syariah Mandiri sebesar $77,70 \%$, petani suka dengan produk yang disediakan oleh Bank syariah Mandiri, petani merasa bahwa Bank Syariah Mandiri memiliki sebuah manfaat untuk petani dalam memenuhi kebutuhan usahatani, produk yang ditawarkan berupa produk penghimpun dana dari masyarakat (funding), produk penyaluran dana kepada masyarakat (financing) dan pelayanan jasa (Fee based income product) membuat petani tertarik untuk menggunakannya, petani tertarik dan senang untuk menggunakan produk bank syariah Mandiri karena produk yang ditawarkan bank syariah Mandiri menggunakan prinsip syariah yaitu bebas bunga dan sistem bagi hasil. Hal ini sesuai dengan pendapat (Asaad 2011) yang menyatakan bahwa tiga 
hal yang menjadi ciri dari pembiayaan syariah, yaitu bebas dari bunga (interest free), bagi hasil serta resiko (profit loss sharing) serta perhitungan bagi hasil dilakukan pada saat transaksi berakhir, hal ini berarti pembagian hasil dilakukan setelah ada keuntungan riil, bukan berdasar pada asumsi bahwa besarnya keuntungan usaha yang akan diperoleh di atas bunga kredit.

Secara konatif sikap petani terhadap produk bank syariah Mandiri dalam kategori setuju atau baik sebesar $77,78 \%$, petani ingin menggunakan fasilitas produk Bank Syariah Mandiri untuk memenuhi kebutuhan permodalan pertanian mereka, petani akan menggunakan produk pembiayaan bank syariah berdasarkan prinsip bagi hasil, sikap petani menunjukan sikap yang positif baik secara kognitif, afektif dan konatif. Hal ini sesuai dengan pendapat (Hurriyati 2005) yang menyatakan bahwa ada tiga komponen pembentuk sikap, yaitu komponen koginitif dapat dipahami sebagai komponen kepercayaan yang didasari oleh pengetahuan, persepsi serta pengalaman mengenai suatu objek. Komponen afektif yaitu emosiemosi yang ada pada diri seseorang dalam kaitannya dengan suatu objek. Komponen konatif dipahami sebagai kesiapan untuk berperilaku tertentu yang didasari oleh suatu sikap tertentu.

Sikap petani terhadap Bank Syariah Mandiri positif karena petani tertarik dan senang dengan produk yang ditawarkan oleh Bank Syariah Mandiri serta ingin mencoba menggunakan produk Bank Syariah Mandiri hal ini terlihat dari sikap yang mereka miliki

tidak menolak adanya bank Syariah Mandiri serta senang dengan adanya Bank Syariah Mandiri. Hal ini sesuai dengan pendapat Sarlito (2012) yang menyatakan bahwa sikap dinyatakan dalam tiga domain ABC, yaitu Affect, Behaviour, dan Cognition. Affect adalah perasaan yang timbul (senang, tak senang), Behaviour adalah perilaku yang mengikuti perasaan itu (mendekat, menghindar), dan Cognition adalah penilaian terhadap objek sikap (bagus, tidak bagus).

Promosi yang dilakukan oleh bank syariah Mandiri dirasa kurang menyeluruh oleh petani serta masih sedikit kantor yang dimiliki oleh bank syariah mandiri, selain itu pesaing yang memberikan kemudahan akses bagi petani membuat sedikit petani yang menggunakan Bank Syariah Mandiri, disarankan kepada bank syariah Mandiri untuk meningkatkan kegiatan sosialisasi dan promosi kepada masyarakat agar masyarakat lebih mengenal dan mengerti produk-produk yang dimiliki oleh perusahaan. Hal tersebut sesuai dengan pendapat Apriyanti (2018) yang menyatakan bahwa terdapat beberapa kelemahan bank syariah diantaranya yaitu promosi bank syariah yang kurang menyeluruh ke berbagai masyarakat, kantor yang dimilki sedikit, ketidaktahuan masyarakat tentang bank syariah, fasilitas anjungan tunai mandiri (ATM) sedikit. Hal ini diperkuat oleh pendapat Sujarwo dan Sari (2017) yang menyatakan bahwa sikap masyarakat terhadap sistem serta produk perbankan syariah menunjukan bahwa sebagian masyarakat tidak mengetahui produk yang ditawarkan oleh perbankan syariah.

\section{Uji validitas}

Pada penelitian ini pengujian validitas terhadap kuesioner menggunakan menggunakan teknik korelasi product moment. Hasil uji validitas dengan SPSS 17.0 menunjukkan bahwa validitas instrumen variabel sikap sebanyak 30 butir pertanyaan seluruhnya diperoleh $r_{\text {hitung }}>r_{\text {tabel }}$ sebesar 0,282, ini berarti variabel 
sikap valid. Hal ini tersebut sesuai dengan pendapat (Ghozali 2011) yang menyatakan bahwa jika $r$ hitung lebih besar dari $r$ tabel dan nilai positif, maka pertanyaan atau indikator tersebut dinyatakan valid.

\section{Uji reliabilitas}

Uji reliabilitas adalah cara atau alat untuk mengukur suatu kuesioner yang merupakan indikator dari variabel untuk mengetahui kuesioner tersebut konsisten atau stabil. Sesuai dengan pendapat (Ghozali 2011) yang menyatakan bahwa suatu kuesioner dikatakan reliabel atau handal jika jawaban terhadap pernyataan adalah konsisten atau stabil dari waktu ke waktu. Berdasarkan dari hasil analisis SPSS 17.0 didapatkan hasil yang menunjukkan koefisien reliabilitas (Cronbach Alpha) adalah reliabel, artinya untuk semua pertanyaan dapat diandalkan atau reliable. Hal ini sesuai dengan pendapat (Astuti 2015) yang menyatakan bahwa kreteria yang reliabel ditunjukkan oleh koefisien reliabilitas lebih besar dari 0,6.

\section{Uji normalitas}

Uji normalitas data dilakukan untuk mengetahui apakah distribusi variabel dependen dalam model regresi yang diajukan berdistribusi normal atau tidak. Data pada penelitian ini diuji normalitasnya dengan menggunakan uji Kolmogorov Smirnov. Berdasarkan hasil uji normalitas menggunakan SPSS 17.0 diketahui bahwa seluruh variabel berdistribusi normal dengan nilai Asymp. Sig. (2-tailed) = 0.526, nilai tersebut lebih besar sama dengan 0,05 sehingga HO diterima yang artinya data tersebut berdistribusi normal. Hal tersebut sesuai dengan pendapat (Muhson 2015) yang menyatakan bahwa langkah uji normalitas untuk mengetahui data berdistribusi normal atau tidak dilakukan dengan cara melihat nilai signifikansi yang diperoleh. Apabila diperoleh nilai a $<0,05$ maka artinya distribusi data tidak normal dan jika nilai $a \geq 0,05$ distribusi data normal.

\section{Uji Asumsi Klasik}

Uji asusmsi klasik dilakukan dengan SPSS 17.0, uji tersebut dilakukan untuk mengetahui apakah model analisis regresi linier berganda ideal serta memenuhi syarat uji. Hal ini sesuai dengan pendapat (Algifari 2015) yang menyatakan bahwa syarat untuk melakukan uji regresi linier berganda adalah data yang diamati harus berdistribusi normal, antar variabelnya tidak terdapat hubungan linier yang kuat (tidak multikolinearitas), varian data konstan (tidak heterokedastisitas), tidak terjadi korelasi residual antar pengamatan (tidak autokorelasi) serta hubungan antar variabel dalam regresi adalah linier. Uji asumsi klasik yang dilakukan terdiri dari uji multikolinieritas, uji heteroskedastisitas serta uji autokorelasi.

\section{Uji multikolinearitas}

Berdasarkan hasil uji multikolinearitas dengan menggunakan SPSS 17.0 diperoleh hasil bahwa seluruh variabel (umur petani, tingkat pendidikan petani, lamanya usaha tani, jumlah tanggungan keluarga dan pendapatan petani) memiliki nilai Tolerance $>0,10$ atau nilai VIF $<10$, sehingga tidak terjadi multikolinieritas serta pengujian dapat dilanjutkan. Suatu model regresi yang baik seharusnya tidak terjadi multikolinearitas antar variabel dependen. Hal ini sesuai dengan pendapat Ghozali (2006) yang menyatakan bahwa nilai Tolerance $>0,10$ atau nilai VIF $<10$ tidak terjadi multikolinieritas. 


\section{Uji autokorelasi}

Uji autokorelasi bertujuan untuk mengetahui apakah ada atau tidaknya korelasi antara variabel pengganggu pada periode waktu tertentu dengan variabel sebelumnya. Hal ini sesuai dengan pendapat Ghozali (2011) yang menyatakan bahwa uji autokorelasi bertujuan untuk menguji dalam model regresi apakah terdapat korelasi antara kesalahan pengganggu pada periode $\mathrm{t}$ dengan kesalahan pengganggu pada periode t-1 (sebelumnya) pada model regresi linier. Berdasarkan hasil uji autokorelasi dengan menggunakan SPSS 17.0 diketahui nilai DurbinWatson sebesar 1,814. Sementara nilai batas atas (du) untuk jumlah responden 47 adalah 1,72 dan sehingga $4-d u=2,23$. Jadi dapat ditarik kesimpulan $d u<d<4-$ du atau tidak terdapat autokorelasi.

\section{Uji heterokedastisitas}

Uji heteroskedastisitas bertujuan untuk menguji terjadinya ketidaksamaan varians dari residual satu pengamatan dengan pengamatan lainnya. Berdasarkan hasil uji heterokedastisitas dengan menggunakan SPSS 17.0 diketahui bahwa seluruh variabel (tingkat pendidikan petani dengan sig. $=0,268$, umur petani dengan sig. $=0,587$, lamanya usaha tani dengan sig. $=0,502$, jumlah tanggungan keluarga dengan sig. $=0,834$ dan pendapatan petani dengan sig. $=0,142)$ memiliki nilai Sig. $>$ Taraf Signifikansi, sehingga $\mathrm{H}_{0}$ diterima serta tidak terjadi heteroskedasitas. Sesuai dengan pendapat Ghozali, (2006) yang menyatakan bahwa apabila masing-masing variabel bebas tidak berpengaruh signifikan terhadap absolut residual $(a=0,05)$ atau Sig. > 0,05 maka dalam model regresi tidak terjadi sebuah gejala heterokedastisitas.

\section{Pengaruh faktor pembentuk sikap terhadap sikap petani}

Analisis regresi dalam penelitian ini bertujuan untuk mengetahui pengaruh umur petani (X1), tingkat pendidikan petani (X2), lamanya berusaha tani (X3), jumlah tanggungan keluarga (X4) dan pendapatan petani (X5) terhadap sikap petani pada produk Bank Syariah Mandiri di Kecamatan Gubug Kabupaten Grobogan. Analisis regresi adalah studi tentang ketergantungan variabel dependen dengan variabel-variabel independen untuk memperkirakan nilai rata-rata variabel dependen berdasarkan pada nilai variabel independen yang diketahui. Hal ini sesuai dengan pendapat (Sukirno 1994) yang menyatakan bahwa analisis regresi akan menentukan suatu persamaan yang menaksir sifat pengaruh fungsional antara variabel dependen dengan variabel-variabel independen. Berdasarkan hasil analisis regresi linier berganda yang dilakukan menggunakan sistem SPSS 17.00 maka diperoleh persamaan sebagai berikut:

$$
\mathrm{Y}=16,803+1,038 \mathrm{X} 1+2,119 \mathrm{X} 2+0,37 \mathrm{X} 3+0,298 \mathrm{X} 4+1,314 \mathrm{X} 5
$$

Keterangan:

$\mathrm{Y}=$ Sikap Petani pada Produk bank syariah

$\mathrm{a}=$ Konstanta

$\mathrm{b}=$ koefisien regresi untuk setiap masing-masing variable

$\mathrm{X} 1=$ umur petani (tahun)

$\mathrm{X} 2=$ tingkat pendidikan petani (tahun)

X3= lamanya usahatani (tahun) 
$\mathrm{X} 4=$ jumlah tanggungan keluarga (jiwa)

$\mathrm{X} 5=$ pendapatan petani (Rupiah)

$\mathrm{e}=$ variabel pengganggu

Persamaan diatas menunjukkan bahwa nilai konstanta positif sebesar 16,803 menunjukkan pengaruh positif pada variabel independen (umur petani, tingkat pendidikan petani, lamanya usaha tani, jumlah tanggungan keluarga, dan pendapatan petani). Bila variabel independen naik atau berpengaruh dalam satu satuan, maka variabel sikap petani akan naik atau terpenuhi. Koefisien regresi variabel umur petani (X1) berpengaruh positif dan signifikan terhadap sikap petani pada produk bank Syariah Mandiri di Kecamatan Gubug Kabupaten Grobogan, nilai koefisien regresi 1,038 memiliki arti bahwa apabila umur petani meningkat 1 satuan maka sikap petani terhadap produk bank Syariah meningkat sebesar 1,038 atau 10,38\%. Hal tersebut selaras dengan pendapat (Rukka dan Wahab, 2013) yang menyatakan bahwa umur merupakan suatu aspek yang berpengaruh terhadap kemampuan fisik, psikologis serta biologisya seseorang.

Koefisien regresi variabel tingkat pendidikan petani (X2) berpengaruh positif dan signifikan terhadap sikap petani pada produk bank Syariah Mandiri di Kecamatan Gubug nilai koefisien regresi 2,119 memiliki arti bahwa apabila tingkat pendidikan petani meningkat 1 satuan maka sikap petani terhadap produk bank Syariah meningkat sebesar 2,119. Hal tersebut selaras dengan pendapat (Azwar 2013) yang menyatakan bahwa berbagai faktor yang mempengaruhi pembentukan sikap salah satunya adalah pendidikan.

Koefisien regresi variabel lamanya usaha tani(X3) berpengaruh positif dan signifikan terhadap sikap petani pada produk bank Syariah Mandiri di Kecamatan Gubug Kabupaten Grobogan, nilai koefisien regresi 0,37 memiliki arti bahwa apabila lamanya usaha tani meningkat 1 satuan maka sikap petani terhadap produk bank Syariah meningkat sebesar 0,37.

Koefisien regresi variabel jumlah tanggungan keluarga (X4) berpengaruh positif serta signifikan terhadap sikap petani pada produk bank Syariah Mandiri di Kecamatan Gubug Kabupaten Grobogan, nilai koefisien regresi 0,298 memiliki arti bahwa apabila jumlah tanggungan keluarga meningkat 1 satuan maka sikap petani terhadap produk bank Syariah meningkat sebesar 0,298.

Koefisien regresi variabel pendapatan petani (X5) berpengaruh positif dan signifikan terhadap sikap petani pada produk bank Syariah Mandiri di Kecamatan Gubug Kabupaten Grobogan, nilai koefisien regresi 1,314 memiliki arti bahwa apabila pendapatan petani meningkat 1 satuan maka sikap petani terhadap produk bank Syariah meningkat sebesar 1,314.

\section{Uji t}

Nilai sig pada variabel umur petani (X1) sebesar 0,032, pada variabel tingkat pendidikan petani (X2) sebesar 0,041, pada variabel lamanya usahatani (X3) sebesar 0,333, pada variabel jumlah tanggungan keluarga (X4) sebesar 0,444 serta pada variabel pendapatan (X5) sebesar 0,016 sehingga dapat disimpulkan bahwa umur petani (X1), tingkat pendidikan petani (X2) dan pendapatan (X5) mempunyai nilai sig $\leq 0.05$ maka Ho ditolak dan Ha diterima sehingga ada pengaruh yang signifikan antara umur petani, tingkat pendidikan petani dan pendapatan petani terhadap Sikap Petani pada Produk bank Syariah Mandiri. Sedangkan pada variabel lamanya 
usahatani (X3) dan variabel jumlah tanggungan keluarga (X4) nilai sig > 0,05 maka Ho diterima dan Ha ditolak yang berarti tidak ada pengaruh yang signifikan antara lamanya usahatani dan tanggungan keluarga terhadap Sikap Petani pada produk bank Syariah Mandiri. Hal ini sesuai dengan pendapat (Sujarweni 2015) pengambilan keputusan uji t adalah apabila sig > 0,05 maka Ho diterima serta Ha ditolak, sedangkan apabila sig $\leq 0.05$ maka ho ditolak dan Ha diterima.

Berdasarkan hasil uji hipotesis diatas, dapat diketahui bahwa faktor-faktor yang mempengaruhi sikap petani terhadap produk bank syariah Mandiri di Kecamatan Gubug Kabupaten Grobogan adalah umur petani (X1), tingkat pendidikan petani (X2), serta pendapatan petani (X5). Sedangkan lamanya usahatani (X3) dan jumlah tanggungan keluarga tidak berpengaruh terhadap sikap petani terhadap produk bank syariah Mandiri di Kecamatan Gubug Kabupaten Grobogan. Hal tersebut terjadi karena petani yang memiliki umur, pendapatan dan tingkat pendidikan yang cukup dapat dengan mudah dalam menerima inovasi sehingga berpengaruh pada sikap yang dimiliki. Petani yang memiliki umur produktif maka memiliki kemampuan fisik yang kuat sehingga dapat bekerja dengan optimal. Umur yang sudah matang juga menentukan kemampuan petani dalam berfikir sehingga dapat mengambil keputusan yang tepat dalam menjalankan usahatani. Hal ini sesuai dengan pendapat Rukka dan Wahab (2013) yang menyatakan bahwa umur merupakan suatu aspek yang berpengaruh terhadap kemampuan fisik, psikologis serta biologis seseorang. Pendidikan juga berperan penting dalam penentuan sikap petani dalam menentukan suatu keputusan, petani yang memiliki pendidikan yang tinggi tentu mudah dalam menerima informasi serta inovasi dari luar.

\section{Uji f}

Uji f digunakan untuk menguji koefisien regresi secara simultan atau bersama-sama antara variabel dependen. Berdasarkan hasil uji SPSS 17.0 (Lampiran 12) didapatkan $F_{\text {hitung }}=3,081>F_{\text {tabel }}=2,41$. Berdasarkan hasil diatas, maka Ho ditolak sehingga secara simultan atau bersama-sama ada pengaruh positif signifikan antara umur petani $\left(\mathrm{X}_{1}\right)$, tingkat pendidikan $\left(\mathrm{X}_{2}\right)$, lamanya usahatani $\left(\mathrm{X}_{3}\right)$, jumlah tanggungan keluarga $\left(\mathrm{X}_{4}\right)$, serta pendapatan $\left(\mathrm{X}_{5}\right)$ terhadap sikap petani pada produk bank Syariah Mandiri (Y). Hal ini sesuai dengan pendapat Ghozali (2009) yang menyatakan bahwa apabila nilai $F_{\text {hitung }}$ hasil regresi $<$ nilai $F_{\text {tabel }}$, maka $\mathrm{H}_{\mathrm{o}}$ diterima. Artinya semakin tinggi keseluruhan variabel maka semakin positif juga sikap petani terhadap produk bank syariah hal ini karena sikap dibentuk dari diri sendiri serta juga lingkungan sekelilingnya, rata-rata petani di kelompok tani Subur Makmur sudah berpengalaman dalam bidang pertanian serta mudah dalam menerima informasi sehingga karakteristik sosial ekonomi seperti umur, pendidikan, lamanya usahatani, jumlah tanggungan keluarga, dan pendapatan petani mempengaruhi pembentukan sikap yang mereka miliki terhadap produk bank Syariah Mandiri.

Umur, pendidikan, lamanya usahatani, jumlah tanggungan keluarga, dan pendapatan memiliki keterkaitan antara satu dengan yang lain, jika tanggungan keluarga besar maka petani harus memiliki pendapatan yang besar pula untuk memenuhi kebutuhan, maka dari itu jumlah tanggungan keluarga dan pendapatan memiliki pengaruh yang positif terhadap sikap petani. Hal ini sesuai dengan 
pendapat (Azmi, Mhd.Rullyanda, Hasman Hasyim 2013) yang menyatakan bahwa karakteristik sosial ekonomi salah satunya yaitu pendapatan mempengaruhi sikap petani serta segala aspek kehidupan petani dalam memenuhi kebutuhan ekonomi.

\section{KESIMPULAN DAN SARAN}

\section{Simpulan}

Berdasarkan penelitian mengenai sikap petani terhadap Bank Syariah Mandiri di Desa Trisari Kecamatan Gubug Kabupaten Grobogan, diperoleh simpulan yaitu faktor yang mempengaruhi sikap petani terhadap produk bank Syariah Mandiri yakni umur petani, tingkat pendidikan, lamanya usahatani, jumlah tanggungan keluarga, dan pendapatan. Sikap petani dalam kategori setuju/baik dengan skor $77,78 \%$. Ada pengaruh yang signifikan antara umur petani, tingkat pendidikan, lamanya usahatani, jumlah tanggungan keluarga, dan pendapatan terhadap sikap petani pada produk Bank Syariah Mandiri di Kecamatan Gubug Kabupaten Grobogan sedangkan berdasarkan uji t didapatkan hasil bahwa umur petani, tingkat pendidikan dan pendapatan secara parsial berpengaruh pada sikap petani terhadap produk bank Syariah Mandiri. Lamanya usahatani dan jumlah tanggungan keluarga secara parsial tidak berpengaruh pada sikap petani terhadap produk bank Syariah Mandiri.

\section{Saran}

Bagi peneliti selanjutnya yang hendak meneliti maupun mengembangkan penelitian serupa, penulis menyarankan untuk melakukan penelitian tidak hanya dalam lingkup faktor-faktor yang mempengaruhi tetapi dapat juga menganalisis variabel lainnya yang berkaitan dengan hubungan antara produk perbankan dengan sikap para petani terhadap produk-produk bank tersebut. Sebaiknya responden dapat meningkatkan pengetahuan tentang Bank Syariah Mandiri sehingga tidak ragu untuk menggunakannya. Saran penulis untuk Bank Syariah Mandiri yaitu memberikan sosialisasi yang intensif kepada petani agar memahami produk Bank Syariah Mandiri sehingga responden lebih percaya terhadap Bank Syariah Mandiri.

\section{DAFTAR PUSTAKA}

Ahmadi, Abu. 2009. Psikologi Sosial. Jakarta: Jakarta: Rineka Cipta.

Algifari. 2015. Analisis Regresi Untuk Bisnis Dan Ekonomi. Yogyakarta.: BPFEYogyakarta, Yogyakarta.

Asaad, Mhd. 2011. "Peningkatan Peranan Perbankan Syariah Untuk Pembiayaan Usaha Pertanian.” MIQOT: Jurnal Ilmu-ilmu Keislaman.

Astuti, P. 2015. "Pengembangan Instrumen Penilaian Unjuk Kerja Praktik Perawatan Kulit Wajah Berbasis Kompetensi Di Universitas Negeri Semarang." Innovative Journal of Curriculum and Educational Technology.

Azmi, Mhd.Rullyanda, Hasman Hasyim, dan Lily Fauzia. 2013. "Pengaruh Karakteristik Sosial Ekonomi Terhadap Sikap Petani Dalam Penerapan Padi Sawah System of Rice Intensification (SRI)Azmi, Mhd.Rullyanda, Hasman Hasyim, Dan L. F. (2013). Pengaruh Karakteristik Sosial Ekonomi Terhadap Sikap Petani Dalam Penerapan Pa.” 
Azwar, Saifuddin. 2013. "Sikap Manusia: Teori Dan Pengukurannya." Sikap Manusia: Teori dan Pengukurannya.

Fauziyah, Elys. 2010. "Analisis Efisiensi Teknis Usahatani Tembakau ( Suatu Kajian Dengan Menggunakan Fungsi Produksi Frontier Stokhastik ).” 7(1): 1-7.

Ghozali. 2011. "Aplikasi Analisis Multivariate Dengan Program SPSS.” Jurnal Mmiah Universitas Pandanaran.

Gusfrianti, Reni, and Rahmita Budiartiningsih. 2010. "Peranan Program Usaha Peningkatan Pendapatan Keluarga (UP2K) Terhadap Peningkatan Pendapatan Keluarga Di Kecamatan Cerenti Kabupaten Kuantan Singingi." Jurnal Ekonomi Universitas Riau.

Hasan, I. 2006. Analisis Data Penelitian Dengan Statistik. Jakarta: Bumi Aksara.

Hurriyati, Ratih. 2005. Bauran Pemasaran Dan Loyalitas Konsumen. Bandung: Bandung: Alfabeta.

Junanda, T. W. 2018. "Analisis Masalah Rendahnya Pembiayaan Pertanian Di Bank Pembiayaan Rakyat Syariah Kabupaten Bogor Dan Alernatif Solusinya." (September): 160-64.

Mantra, I.B.D. 2003. Defografi Umum. Edisi Kedu. Yogyakarta: . Pustaka Pelajar. Yogyakarta.

Marimin, Agus, and Abdul Haris Romdhoni. 2017. "Perkembangan Bank Syariah Di Indonesia." Jurnal Ilmiah Ekonomi Islam.

Muhson, A. 2015. Aplikasi Komputer Lanjut. Yogyakarta: Universitas Negeri Malang.

Oktavia, E. 2018. "Analisis Persepsi, Pengetahuan Dan Sikap Nasabah Terhadap Keberadaan Bank Syariah." Fakultas Ekonomi dan Bisnis islam. Universitas Islam Negeri Raden Intan Lampung (September): 160-64.

Rukka, H. dan A, Wahab. 2013. "Faktor - Faktor Yang Mempengaruhi Motivasi Petani." 9(1).

Sinuraya, M., Barus, A. Hasanah, Y. 2015. "Respons Pertumbuhan Dan Produksi Kedelai (Glycine Max (L.) Meriil) Terhadap Konsentrasi Dan Cara Pemberian Pupuk Organik Cair.” Jurnal Online Agroekoteknologi 4(1): 1721-25.

Sitopu, Reslila, Lily Fauzia, and Jufri. 2014. "Partisipasi Petani Dalam Penerapan Usahatani Padi Organik (Studi Kasus Desa Lubuk Bayas Kecamatan Perbaungan Kabupaten Serdang Bedagai)." Journal on Social Economic of Agriculture and Agribusiness.

Sujarweni, V.W. 2015. "Metodologi Penelitian Bisnis Dan Ekonomi." Paper Plane. Yogyakarta.

Sukirno, Sadono. 1994. "Pengantar Ekonomi Makro Edisi Ketiga.” Jakarta: Rajawali Pers. 